\title{
Working life in the Nordic region
}

\section{Challenges and proposals}

/ Poul Nielson

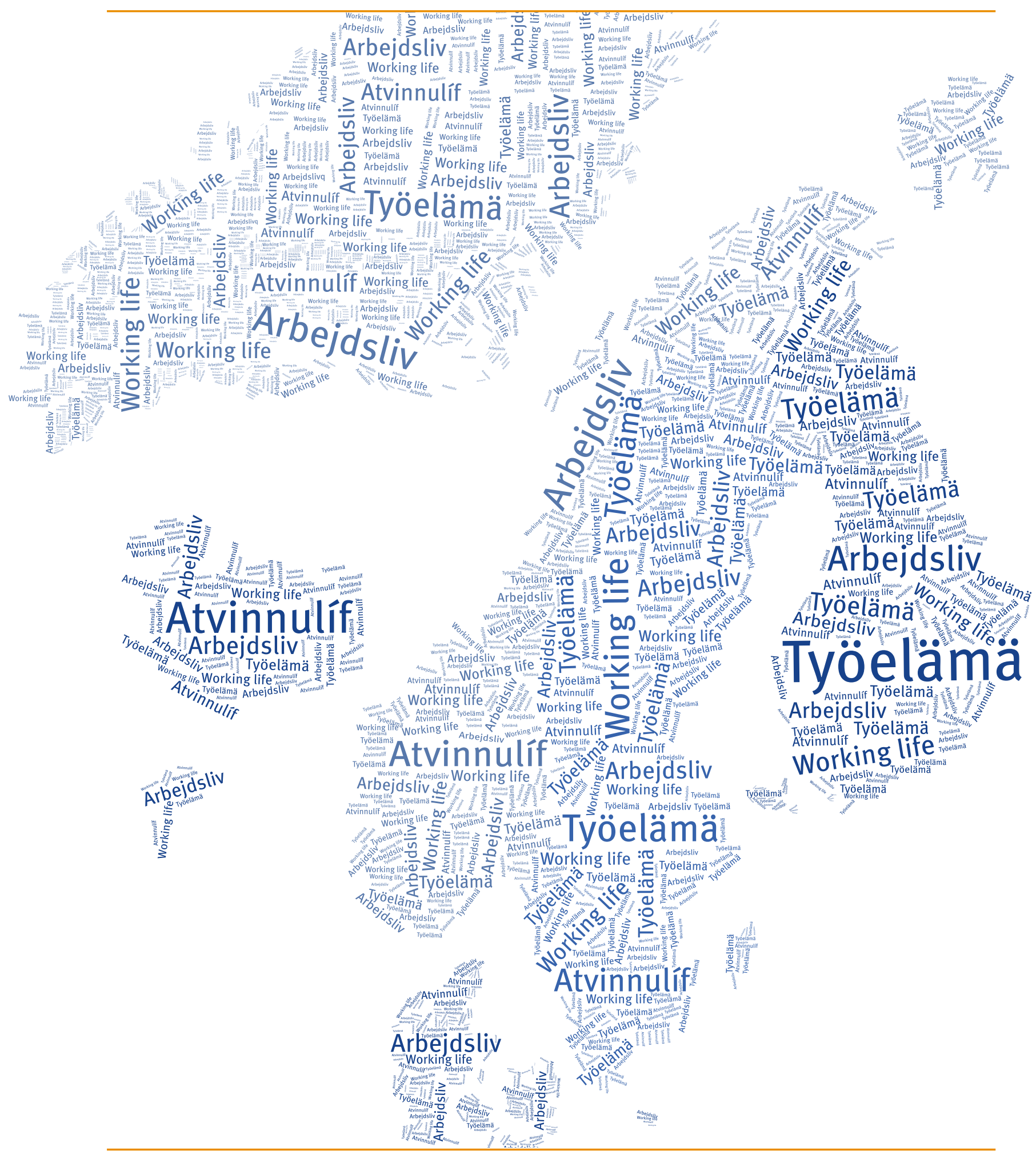



On 20 November 2014 the Nordic ministers for labour in the Nordic Council of Ministers decided to carry out a strategic examination of Nordic co-operation in the field of working life. The report was to contain 10-15 specific action-oriented proposals for improving Nordic co-operation in the field of working life over the next 5-10 years. In April 2015 I agreed to assume this task.

Since then I have had extensive consultations with ministers, parliamentarians, civil servants, researchers and representatives of employers and trade unions throughout the Nordic region and meetings with the EU Commission, the European Parliament, European think-tanks, the ILO and the OECD. My work on the report involved over 100 interviews, and among other things I went through the minutes of several years of ministerial meetings. In writing the report I have chosen to omit specific references - also because this better reflects the fact that I alone am responsible for the content of the report.

I have encountered great interest and helpfulness from all concerned in this undertaking, which has vindicated the timeliness of the decision to carry out this analysis. I would like to thank all of the many people who have contributed their insight, experiences and views in the process. Particular thanks go to the Secretariat of the Nordic Council of Ministers and in particular Senior Adviser Ulf Andreasson, who has been both a good friend on the many trips and an inspiring and shrewd sparring partner in the process. 


\section{Working life in the Nordic region - Challenges and proposals}

ISBN 978-92-893-4580-4 (PRINT)

ISBN 978-92-893-4581-1 (PDF)

http://dx.doi.org/10.6027/ANP2016:735

ANP 2016:735

(c) Nordic Council of Ministers 2016

Layout: Jette Koefoed/Erling Lynder

Cover Photo: Erling Lynder

Photos: p. 8, Yadid Levy; p. 22, 33, ImageSelect;

p. 26, Karin Beate Nøsterud

Type: Meta LF

Paper: Munken Polar

www.norden.org/nordpub

\section{Nordic co-operation}

Nordic co-operation is one of the world's most extensive forms of regional collaboration, involving Denmark, Finland, Iceland, Norway, Sweden, and the Faroe Islands, Greenland, and Åland.

Nordic co-operation has firm traditions in politics, the economy, and culture. It plays an im-portant role in European and international collaboration, and aims at creating a strong Nordic community in a strong Europe.

Nordic co-operation seeks to safeguard Nordic and regional interests and principles in the global community. Common Nordic values help the region solidify its position as one of the world's most innovative and competitive.

\section{Nordic Council of Ministers}

Ved Stranden 18

DK-1061 Copenhagen K

Phone (+45) 33960200 


\section{Working life in the Nordic region}

Challenges and proposals

$\begin{array}{lc}\text { Introduction } & 6\end{array}$

Substantive, common Nordic topics $\quad 9$

Obstacles to cross-border freedom of movement 9

$\begin{array}{ll}\text { Migratory pressures } & 10\end{array}$

$\begin{array}{ll}\text { Statistics } & 11\end{array}$

$\begin{array}{ll}\text { Working environment } & 12\end{array}$

$\begin{array}{ll}\text { Gender equality } & 14\end{array}$

Structural changes and the representativeness of organisations 15

$\begin{array}{ll}\text { Education and training } & 18\end{array}$

$\begin{array}{ll}\text { The western Nordic region } & 20\end{array}$

$\begin{array}{ll}\text { Institutional topics } & 23\end{array}$

$\begin{array}{ll}\text { Nordic Council of Ministers for Labour } & 24\end{array}$

$\begin{array}{ll}\text { The Nordic region in the EU } & 27\end{array}$

$\begin{array}{ll}\text { Description } & 27\end{array}$

What can the Nordic region do? $\quad 30$

The Nordic region in the world 33

International Labour Organisation (ILO)

$\begin{array}{ll}\text { OECD } & 34\end{array}$ 


\section{Introduction}

Apart from a number of differences

between the countries in the Nordic region

as regards the structure and policies of their labour markets generally, there is a core of common types of approaches, standards and values which together define the nature of working life and labour market policy in the Nordic countries so that one can speak of a "Nordic model", which in important areas is distinct from conditions in the labour market in most other countries - both in Europe and the rest of the world.

Over time we have developed a negotiating culture in the Nordic region between employers and employees founded on an understanding of the value of a wellorganised labour market and where the state and the legislator have a detached and supporting role. An organisation rate that is high by international comparisons both on the employee and employer side has underpinned both the legitimacy and the functioning of the model. One can say that a "compromise competence" has been built up that is in contrast to relations between the two sides of the labour market in many other places.

It is essential to understand that this development has not taken place in a social or political vacuum but in a historical context with the establishment of our Nordic welfare societies based on a recognition of the social and human responsibility of the community. And just as there is a distinction between the Nordic region and many other countries in the labour market, the Nordic countries also stand out in that they are characterised by less inequality and greater social security than most other countries. The political negotiating culture, where proportional representation has fostered a degree of pragmatism and a need for compromises, also chimes with the development in the labour market. This overall development has also led to prosperous and well-functioning societies. So when the Nordic model is referred to throughout the world, one does not only think of labour market conditions, but of the nature of our societies as a whole. The theme of this report is not social policy in general, but working life and cooperation around it in the Nordic region. But there are many aspects to working life, and they cannot be clearly demarcated from other areas (e.g. education, health, migration). The democratic welfare society and the Nordic labour market model are preconditions for each other.

The Convention Concerning a Common Nordic Labour Market of 1954 was a 
progressive decision that has contributed to growth and employment in our countries. But over the last 20 years there has not really been a concomitant follow-up in terms of a systematic effort towards harmonisation and integration in the Nordic region in the various areas of working life. We should therefore explore ways in which common solutions can preserve and strengthen the values that we have in common and that can provide a response to the challenges we face today. It is not difficult to spot the challenges: globalisation and technological developments, structural changes in the labour market, the difficulty of maintaining high organisation rates, the flow of refugees, global migratory pressures and the side-effects of freedom of movement for enterprises and employees in Europe. The process in the EU, with the establishment of a labour market policy which from directive to directive - and from judgement to judgement - aims to create common rules to secure the fundamental principles of the Treaties and the creation and protection of rights on both sides of the labour market, has in practice meant that the Nordic countries have to a large extent been placed in a reactive position, where implementation of directives and compliance with court rulings are taking precedence over a pro- active effort to formulate a common policy and seek influence on the very substance of the European process. The desire to create a more markedly Nordic effort in the field of working life should not, however, only be seen as a defensive endeavour to cling on to our principles and values. We have good reason to react positively, and jointly, to the interest shown in many quarters in the Nordic model. An active branding of our ways of working, standards and values in working life is quite simply a positive proposition for the outside world.

For the sake of clarity it should be noted that in the drafting of the report it was a conscious choice not to go into the particular conditions of the public sector.

The challenges and the opportunities for identifying new ideas that could strengthen co-operation in the Nordic region in the field of working life can be divided into four categories:

- Substantive, common Nordic topics

- Institutional topics in Nordic co-operation

- The Nordic labour market and the EU

- The Nordic region in the world. 


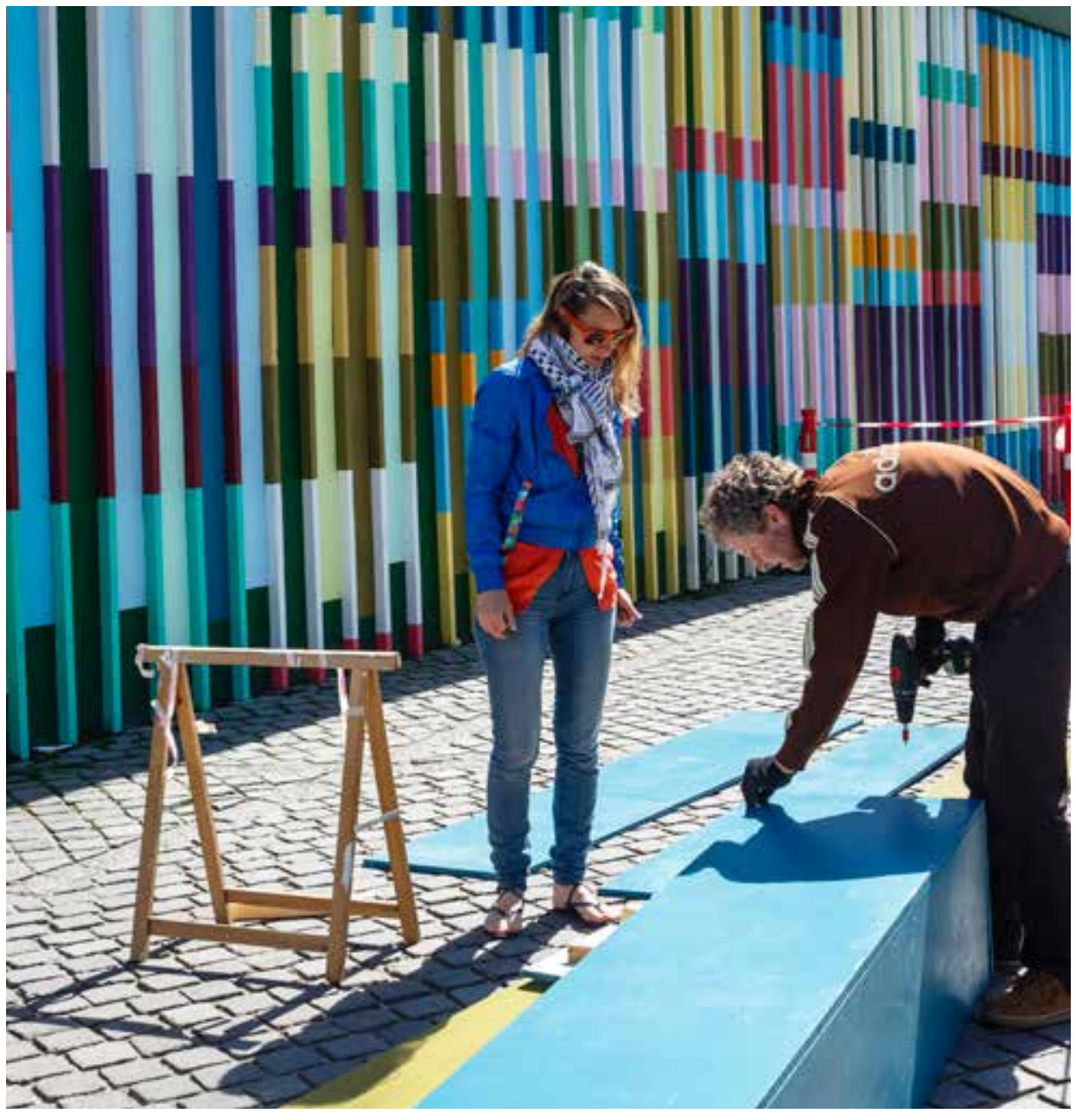




\section{Substantive, common Nordic topics}

\section{Obstacles to cross- border freedom of movement}

Work to remove various impediments and obstacles to cross-border freedom of movement is an important part of the endeavour to bring about a truly common labour market in the Nordic region. The working method of the Freedom of Movement Council is a meaningful and direct way to push for solutions to the various problems. Just to mention some of these: recognisation of professional authorisations (e.g. certified electricians) and better monitoring and follow-up in the other countries in cases where the authorities in one country have e.g. removed a doctor's licence; problematic interaction between unemployment benefit rules and unemployment funds; student grants and taxation. Regarding technical standards in construction, the Freedom of Movement Council points out year after year that the fact that many of these are determined by sectoral business organisations in the various countries makes it difficult to tackle the problem through legislation!

\begin{abstract}
All these obstacles represent real, and often significant, inconveniences for the citizens and companies concerned, especially in border regions, even though nationally the problems do not carry much weight. One reason for the inertia in accommodating the desire for changes is that in many cases it would require thorough and fundamental changes in e.g. taxation systems to eliminate something that is a problem for relatively few persons. In such cases it might be an idea to create a sort of virtual, borderspecific jurisprudence for a clearly defined group of affected citizens without altering the overall system. If the systems cannot be harmonised, but the objective is nonetheless to remove obstacles to the freedom of movement, there should be customised, specially negotiated and demarcated border solutions. As far as the $\emptyset$ resund region is concerned, this proposal could be referred to illustratively as a "legal virtual Hven".
\end{abstract}

Proposal 1: The work of the Freedom of Movement Council should be supplemented with an examination of the possibility to create solutions that cut across established systems affecting limited and specifically defined groups of persons. Such an examination must necessarily be a joint Nordic task on the basis of explicit support from the governments. 


\section{Migratory pressures}

It would appear totally divorced from reality to talk about obstacles to freedom of movement in the Nordic region without including the pressure on our labour markets following the influx of refugees and global migratory pressures. Within a short time the proportions have become such that this challenge has topped all the other already identified problem areas such as labour market training, youth unemployment, social dumping, a weakening of the organisation rate and the challenge of countering the tendency towards increased inequality.

The consequence of this is that the area of politics focused on the labour market and working life more generally has become one of the weightiest issues on the overall political agenda. In the short term it is pointless to talk of "labour market policy as usual". It will therefore be necessary to confront the governments of the Nordic countries and ask them to what extent they wish to co-operate to hold on to the basic principles in the common Nordic labour market and the values that are the core of the model - regardless of the extra challenges we face from refugee and migratory pressures. This question needs to be asked both in relation to managing immigration in the short term and to what this means for working life in the Nordic region in the longer term.

Seen from the outside, the way the governments of the Nordic countries have handled the problem has not strengthened the picture of the Nordic region as an entity that stands out with close, well- co-ordinated co-operation. The absence of an effectively administered common European refugee and immigration policy as a reference point does not make this easier. Nor have the Nordic countries as a group so far contributed to facilitating the formulation of such a policy.

The fundamental, overarching aspects of refugee and immigration policy are beyond the scope of this report. But the fact remains that the list of challenges facing working life in the Nordic region remains essentially unchanged - but now with a weightier layer of problems on top of it all. Our common will and ability to meet the challenges based on the values at the core of the Nordic model will determine whether immigration can end up being a positive resource in our societies. For gender equality, and in particular for immigrant women, it is essential that these values are upheld.

All the indications are that early participation in working life - combined with an element of language teaching etc. - is a better way forward than spending several years on preparatory activities. Learning by doing is a good motto for the integration effort. Experience-sharing is a vital, established quality in Nordic cooperation and this will also apply to the way migratory pressures are handled. But more is needed. A systematic common effort is necessary. In the light of the crucial importance of participation in the labour market for integration efforts, the Nordic Council of Ministers for Labour (MR-A) ought to be in the forefront of this, even though a cross-sectorial approach is required.

Proposal 2: $\quad$ A special working group should be set up under the Council of Ministers to collect updated state-of-play reports on an ongoing basis, carry out consolidated joint analyses (an ongoing Nordic peer review) and present proposals and recommendations for initiatives. The working group should contribute to creating the basis for a more substantial and action-oriented joint Nordic political effort in line with our fundamental values. 


\section{Statistics}

In talks throughout the Nordic region, there have been calls from many parties for more determined efforts to improve the production of statistics relevant to working life generally. There are many areas where incompatibility creates problems, not just in research and education, but also for practical co-operation. To give a clear example of this, it has not been possible to produce joint, unambiguously defined statistics on the number of posted workers in the Nordic region. The Freedom of Movement Council also refers to the need for better common statistics.

In many cases there are of course good reasons why statistical definitions and methods reflect particular legislative and practical circumstances, and many of these problems cannot simply be narrowed down to labour market statistics. But the problems of statistical comparability are so real that they in themselves impede proper exchange of experiences and the formulation of joint policy. The fact that e.g. Eurostat, the OECD and the ILO obviously face even greater challenges than the Nordic countries in producing comprehensible and directly comparable definitions and descriptions of unemployment figures, accidents at work, the working environment, gender equality, conditions for persons with disabilities etc. does not make the task any easier.

A number of initiatives have already been launched in this area, but this is clearly an area of work where a joint Nordic effort would be useful, not just for the development of Nordic co-operation, but would also be an activity that would demonstrate the capacity of the Nordic countries to contribute ideas and solutions that would be welcomed internationally. Although the emphasis needs to be on labour market statistics, an initiative of this type from the Nordic countries could stimulate better co-operation more broadly in the endeavour to improve statistics in the international community.

Proposal 3: The Nordic governments should set up a steering group involving relevant expertise from authorities, universities and the social partners, initially to draw up a problem list of shortcomings and technical criticisms, and subsequently draw up a priority list of these and present proposals to achieve better quality and compatibility in labour market statistics. Ultimately, this work should link into the work in the ILO, OECD and EU on improving the production of statistics. Co-ordination and support for the work of the steering group should be provided by the Secretariat to the Nordic Council of Ministers. 


\section{Working environment}

The working environment is set to become a key problem area in working life in the future and also something that will place greater demands on the interplay between the social partners and the state. Later retirement, faster technological development and global competition will mean efforts to achieve a good working environment must be prioritised if quality of life is to be maintained at the workplace.

Greater Nordic co-operation is advisable on three issues in particular in the working environment area: the psychological working environment, enhanced joint Nordic efforts in work in the EU's expert committees which set standards, limit values etc. and a review of experiences of labour inspection in the working environment area.

The Nordic Institute for Advanced Training in Occupational Health (NIVA) has considerable competence in facilitating and educating health and safety experts and practitioners, including labour inspectors, and in further education. The institute would be a valuable component in implementing cross-sectoral initiatives in this area.

The psychological working environment needs to be upgraded, both perceptionwise, in terms of research and politically The role of the state in relation to the social partners in this area and the right of inspection bodies to intervene more authoritatively in psychological working environment versus the autonomy of business management varies from one Nordic country to another. This makes the psychological working environment an obvious area where Nordic legislation could be harmonised. Since there are relatively few dedicated experts in the field in the individual countries, it would also be right both professionally and politically to strive for better co-ordination of activities and projects in this domain. Authorities, researchers and organisations ought to prioritise projects of joint interest when they work together. Networks are good, but in the Nordic region more is needed.

The work in the EU's expert committees is of great practical importance for the requirements, limit values etc. adopted in the working environment area via directives etc. The Nordic region has considerable potential expertise spread over various institutions and research environments in the countries, and very many meetings take place in the various specialisations within the working environment area. A more organised and targeted effort between these networks and the authorities in the Nordic region could strengthen our influence and furthering our interests in the ongoing work in the EU.

As regards inspection, three particular questions emerge: the quantitative effort, self-monitoring and inspection as an inspection method and the effect on maintenance of quality and the scope of supervision in the light of the increased use of subcontractors, temporary employment agencies and the growth in independent self-employment. In this context the interaction between labour inspection and other authorities such as the tax authorities and the police is fundamental. A joint, continually updated Nordic database of particularly problematic cases and a comparative review of the situation in the three areas listed here could be useful. 
Proposal 4: The Council of Ministers should decide to upgrade efforts regarding the psychological working environment. The possibility of true Nordic harmonisation of legislation in the area should be studied, putting the psychological working environment on an equal legal footing with the physical environment. In any case a joint Nordic working programme should be developed to gather best practices, identify and develop more structured forms of co-operation in the area in the Nordic region and involve the Nordic region in a more sustained and pro-active manner in co-operation in this area in the EU.

The Working Environment Committee under the Nordic Committee of Senior Officials for Labour should draft proposals for enhanced Nordic participation in and shaping of the work in the EU's expert committees in the working environment area.

Exchanges of experiences between ministers on inspection of the working environment should be supported by independently produced proposals for thematic discussions with particular emphasis on the three issues raised here. 


\section{Gender equality}

Lower wages remain a reality for women in some areas of employment. The problem is not being alleviated by the tendency towards lower organisation rates and the "crowding in" effect on the worst paid and worst educated section of the labour market. The structural background to this is of course general and not specifically directed against women in the labour market. But it is a factor that prolongs and intensifies the problem of discrimination, and therefore deserves attention. With the current migratory pressures and the challenge of integration into the labour market, a particular need has arisen to ensure that the position of women does not end up in a sort of gender-policy cultural blind alley blocking gender equality in the longer term. For this reason too we should remind ourselves of the positive gender equality impact that e.g. the presence of well-staffed childcare facilities has had for the position of women in the labour market. A critical quantitative and qualitative updating of these facilities would enhance gender equality in the labour market - not least for female refugees and immigrants.

The introduction of mandatory adult and further training as proposed in this report could contribute to reducing the educational and career lag that many women experience compared to their male colleagues.

A particular aspect of significance for gender equality is the relatively lower level of diversity in the economic structure and thereby in the educational make-up in the peripheral regions in the Nordic countries, first and foremost Greenland and the Faroe Islands, but also Iceland. Again this is not something that is directed solely against the situation of women, but something that in practice complicates gender equality in the labour market.

\section{Proposal 5: $\quad$ The gender equality issue should be prioritised in a fully horizontal} manner in co-operation in working life in the Nordic region. 


\section{Structural changes and the representativeness of organisations}

Although there are differences between trade union organisation rates in the Nordic countries, a common feature is that a number of factors have contributed to a weakening of the high organisation rate that characterised industrial society in the years when the Nordic welfare societies were being created. The rise of a highly diversified service sector and the growth in small companies in communications, consultancy etc. have altered the classic structure in the labour market. Moreover, at least in one of the Nordic countries, competing professional organisations have emerged which offer members a cheaper alternative, but do not cover the spectrum that the traditional bodies offer in the form of real negotiating power in collective agreements and a range of services in areas like the working environment, further training etc. An increased tendency to use temporary employment agencies and subcontractors, and the varying commitment of foreign companies, has also fragmented the labour market, especially in certain sectors such as construction. Finally, immigration, both from EU countries and beyond, has increased the supply of only partially integrated labour, especially at the bottom of the qualification hierarchy.

Structural changes have affected the classic situation on the employers' side too. Today it is a major challenge to unionise many companies in new sectors where the culture and perhaps also the relationship between owners and employees is different than in industry. Additionally there is a tendency for large international groups - "the powerful singles" - to pursue their interests independently of employers' organisations - regardless of whether they are members of them or not. All in all, therefore, both sides of the labour market face a common challenge in maintaining the authority and legitimacy of their central role in the negotiating model. Notwithstanding the natural conflicts of interest that constantly define the content of negotiations, there is a recognition of a joint responsibility to maintain a state of affairs in the labour market where it is possible to make binding agreements that ensure stability and predictability, and where this way of defending respective interests also forms the basis for considerable joint influence on social policy more generally.

There is an extensive Nordic network and co-operation both on the employees' and employers' side, even though actual negotiations are naturally conducted more or less centrally on a national basis. Cooperation between employers is informal rather than extrovert in nature, but is clearly structured. On the employees' side, the Council of Nordic Trade Unions (NFS) represents a more formalised and explicit organisational culture. Whilst the pressure on representativeness described above is generally recognised as a worrying problem politically, in keeping with the basic agreement that it is not for the state to determine organisational arrangements in the labour market, this is in principle a challenge that the organisations themselves must address. It is important to recognise, however, that the existence of representative organisations in the labour market that are competent to negotiate can in fact be seen as a resource that in many contexts, both generally and in tandem with the state and the legislative authority, enables solutions in 
the Nordic region that are not possible in societies where similar conditions do not prevail in the labour market.

In practice there are a number of areas where legislation and administration directly affect the background and opportunities for strengthening organisations' representativeness, primarily on the employees' side. Taxation rules in relation to unemployment fund and trade union subscriptions are an example of this. Differences of this type are typically treated as variants of obstacles to cross-border freedom of movement, but are in this context rather obstacles to organisation. In a number of respects this can naturally also be seen as a politically controversial problem area. But to the extent that we take seriously the importance of retaining the value and the functioning of the Nordic labour market agreement model, we must also acknowledge that there are areas where it is meaningful to contributing politically. And inasmuch as we would like labour market co-operation in the Nordic region not just to be about the common labour market as such, but also about there being a common challenge in Nordic cooperation to contribute to the quality of this, it would be appropriate to look at the ways the countries and their co-operation can strengthen representativeness in the agreement model in the dialogue between the governments.

To an even greater extent than the factors flagged up here, technological changes, structural changes in the economy and not least the emergence of new forms of organisation of working life are contributing to the erosion of organisations' representativeness. Individuals perform tasks for companies without any regular employment relationship being established.
Distance work, not least IT functions, communications and various forms of consultancy, are performed on the basis of more or less formalised contracts, but typically without security for these selfemployed persons as regards termination of the employment relationship, pensions, parental leave, holiday pay or many other rights which are settled in regular employment relationships, where professional organisations and the exercise of regular employer's responsibility is the employment context. Many service areas are increasingly dominated by a working life that does not necessarily lie within the confines of the formal economy, which is in itself a serious societal problem. Many especially the more affluent - simply see this development as a private matter, and something that is felt is consistent with a desire for freedom and independence. But the reality is that most of those who end up in the "self-employed" category do so out of necessary due to the difficulty of getting a regular job, not as a preferred alternative.

There is a huge divide between the situation of a highly educated academic with special qualifications and the predicament of most others in this growing market of day-labourers. Without the security that a classic organisation gives the members of a trade union, a growing group of self-employed persons will over time put the public social security system under pressure. At the same time, further erosion of trade union membership and fragmentation of the organised employer's role will weaken the authority of both parties in the exercise of their joint responsibility for stability in the labour market. All in all this is a development that conflicts with the values we wish to safeguard in the Nordic labour market. 
This development has attracted a great deal of attention internationally. In a major project entitled "The Future of Work", the ILO proposes focusing on these issues as a key topic in connection with the commemoration of the organisation's 100th anniversary in 2019. The OECD is also putting considerable resources into the area. Both organisations see the group of Nordic countries as a welcome and important partner in efforts to find solutions to the problems entailed by the fragmentation of working life. The EU Commission also considers this development as something that further complicates efforts to achieve stable and orderly conditions in the European labour market through a broad-based dialogue with the social partners.

The trade union movement is based on the organisation of wage earners at workplaces and safeguarding their interests through collective agreements with employers. "Selfemployed" in its various guises does not fit into this model. Another complicating factor is that there is a degree of uncertainty among employers as to how to respond to this phenomenon, which is moving economic activity away from well-defined structures, and which is also hard to square with companies' efforts to highlight their Corporate Social Responsibility. One could term this employers' "Organised Social Responsibility".
Even though new trends tend to attract disproportionate attention, there is nothing to indicate any let-up in the fragmentation of the labour market. Therefore it is a challenge, especially for the trade union movement, to develop new forms of organisation and services for the diverse group of self-employed persons to make the individual's situation secure even if he or she is not employed at a workplace as with traditional wage earners. In the quest for ideas to develop this sort of hybrid organisation, one could look to the ways in which e.g. freelance journalists, artists and similar independent operators are organised. The state's role ought to be to support organisations' work by finding solutions to these challenges so as to ensure a working balance between the public social system and the conditions in this different part of the labour market.

Employers will face a similar challenge in filling the organisational vacuum created by the fragmentation of the economic structure. It is essential to underline that society's overall interest in the development of new, more appropriate and flexible forms of organisation implicates employers' and employees' organisations to an equal extent.

\section{Proposal 6: On the basis of preparatory work in the Nordic Committee of} Senior Officials for Labour, the ministers should discuss specific legislative conditions, including taxation, which may curb the representativeness of labour market organisations. Together with the Secretariat and the social partners in the Nordic region, the Nordic Committee of Senior Officials for Labour should draw up a proposal for a thematic discussion between the ministers with the further goal of arriving at a list of ideas for use in efforts in the Nordic region and internationally to adapt to the demands we face from the fragmentation of working life. 


\section{Education and training}

There is general agreement in all the Nordic countries that more education is a crucial part of the response to the challenge posed by globalisation, digitalisation and technological advances in general. This is not just in relation to the competitiveness of industrial society, but is equally central in a services-oriented knowledge society. The combination of rapid technological changes and a progressively higher retirement age further increases the need for something new in the education area. On top of this there is the general extra pressure on capacity in the education system from migratory pressures. Maintaining high levels of prosperity and a humanly satisfying working life that can be expected to be longer than today are premises that we largely take for granted as part of the Nordic model. But for the Nordic countries to be able to maintain their position in global competition in the future, something else is required within education and training, and not just more of the same. The challenge is not to work harder, but to work smarter.

The observation that more ambitious efforts are required in the field of education is nothing new. Considerable resources are devoted to adult education and in-service training, often closely linked to companies' or institutions' needs and run by them, but also in the form of employees' right to in-service training as negotiated between the social partners. The general picture is that academics, by virtue of the nature of their work, are more involved in continuing training throughout working life than other groups, but there is also an increasing tendency for skilled workers to complete training that moves them up the skills hierarchy.
The problems of the large group of young people who do not make progress in the education system after leaving school is naturally the subject of considerable attention in all the countries. It is not the intention to go into details about the various areas of education and training in this report on working life in the Nordic region. But a broad-based general approach is essential in order to create a higher baseline in the labour market. This is both because this will deliver a better starting point for involving this labour market category in further training, and partly because migratory pressures simply mean that there is no alternative to making major efforts in this area.

To prepare ourselves for the future we need to think out of the box in education and training. It would be a visionary decision if the Nordic countries, jointly and with the involvement of the social partners, developed a model for putting into practice the principle that adult education and in-service training will be a mandatory element of working life. The creation of the common Nordic labour market in 1954 was not a routine decision either. There will be many misgivings, conflicts of interest and not least great difficulties in the allocation of costs and rights regardless of what models are envisaged for this. Owing to the duration of training initiatives, there should naturally be a progressive approach as regards the level of ambition. But something of this type, something that affirms our societies' capacity for innovation and can lift the Nordic countries into a winning position in the global competition, deserves to be tried.

One can imagine two basic models in the attempt to make this vision a reality. The systemically most ambitious would be a joint development project decided 
by the Nordic Council of Ministers and with a joint Nordic steering group with the participation of the social partners, where pilot projects in the various countries comprising various parts of the labour market could be used to test their feasibility and to determine the costs. The public sector needs to accept this approach as a necessary and forward-looking continuation of the investment in education and training that has been the pattern hitherto. After all, the fact that children and young people need to be educated, and that society has a responsibility for this, has not been controversial for over 100 years. The involvement of labour market organisations will be essential - not least because it is they, consistent with the negotiated basis of the evolution of working life, who will be able to ensure a balance between obligations and rights in such a system, as well as the relevance of the content of mandatory adult training.

The other basic model is perhaps less systemic and ambitious and would be based on an organic and less controlled increase in agreements between the parties that would progressively cover more and more of the overall labour market, adapted to the many different conditions that prevail from sector to sector etc. The role of the state in this model would be to facilitate and economically encourage this development. The role of Nordic cooperation in this model would be to bring together initiatives and agreements, ensure immediate exchange of experiences and stimulate the dissemination of best practices.

Regardless of which model might be decided by the governments, the very fact that something of the sort is being launched in the Nordic region would contribute to increased understanding of the potential we have in the innovative negotiating culture in the Nordic model. Just as the Nordic countries were in the forefront in 1954 with the creation of a joint labour market, today we ought to be in the forefront in meeting the challenges of the future.

Proposal 7: $\quad$ The Nordic governments should commit to the principle of introducing mandatory adult and continuing training for everybody in the labour markets in the Nordic region and, together with the social partners, should decide to implement experimental activities via joint pilot projects as described here in the two basic models for implementation of the principle.

In connection with this necessary upgrading of education and training as a more systematic and integrated part of working life in the future, it will be important for society and the social partners to show responsibility and solidarity to that category of citizens who quite simply are unable to keep up, for whom the requirement of upskilling is perceived more as a threat than an opportunity. It is politically incorrect to say it, but it is disingenuous to claim that everybody can be educated to fulfil a productive and meaningful role in the labour market of the future. In tandem with the competitive demands of digitalisation, technological advances and globalisation, we must be prepared for the likelihood that this residual group will increase, and society must prepare to provide these citizens a secure and decent existence. It is of course not easy to define the boundaries of this category in terms of labour market policy and social policy. The point is, however, that the easy answers that "everybody can do something, everybody can learn something and must have a job" are not necessarily either realistic or especially humanely compassionate. 


\section{The western Nordic region}

For reasons of geography and the economic structure, the labour market conditions in the Faroe Islands, Iceland and Greenland are radically different from the situation in the rest of the Nordic region. But training young people and efforts to combat youth unemployment are a familiar challenge throughout the Nordic region. Many young people leave for other countries - both in the Nordic region and beyond - for higher education, and many do not return. The co-operation in distance learning in legal training between the University of Aalborg and the universities in Greenland and the Faroe Islands could be an example of actions to lessen this trend.
The limited diversity in these relatively small economies, which are dominated by the fisheries sector, means that the need for job creation at all levels is especially important. Moreover, relatively extensive commuting, or more or less permanent migration, to jobs in the Nordic countries (e.g. workers from the Faroe Islands in the Norwegian oil industry or construction) makes planning or initiatives more complicated. As indicated above, the economic structure in the western Nordic economies may also be a factor affecting gender equality.

In relation to the Faroe Islands, Iceland and Greenland, language may act as an obstacle to educational and occupational integration in the rest of the Nordic region.

Proposal 8: The particular challenges that exist for job creation in the western Nordic region should be the subject of a special study conducted in collaboration between the Nordic Committee of Senior Officials for Labour and the Secretariat, the conclusions of which should form the basis of the ministers' deliberations and the positions adopted. 



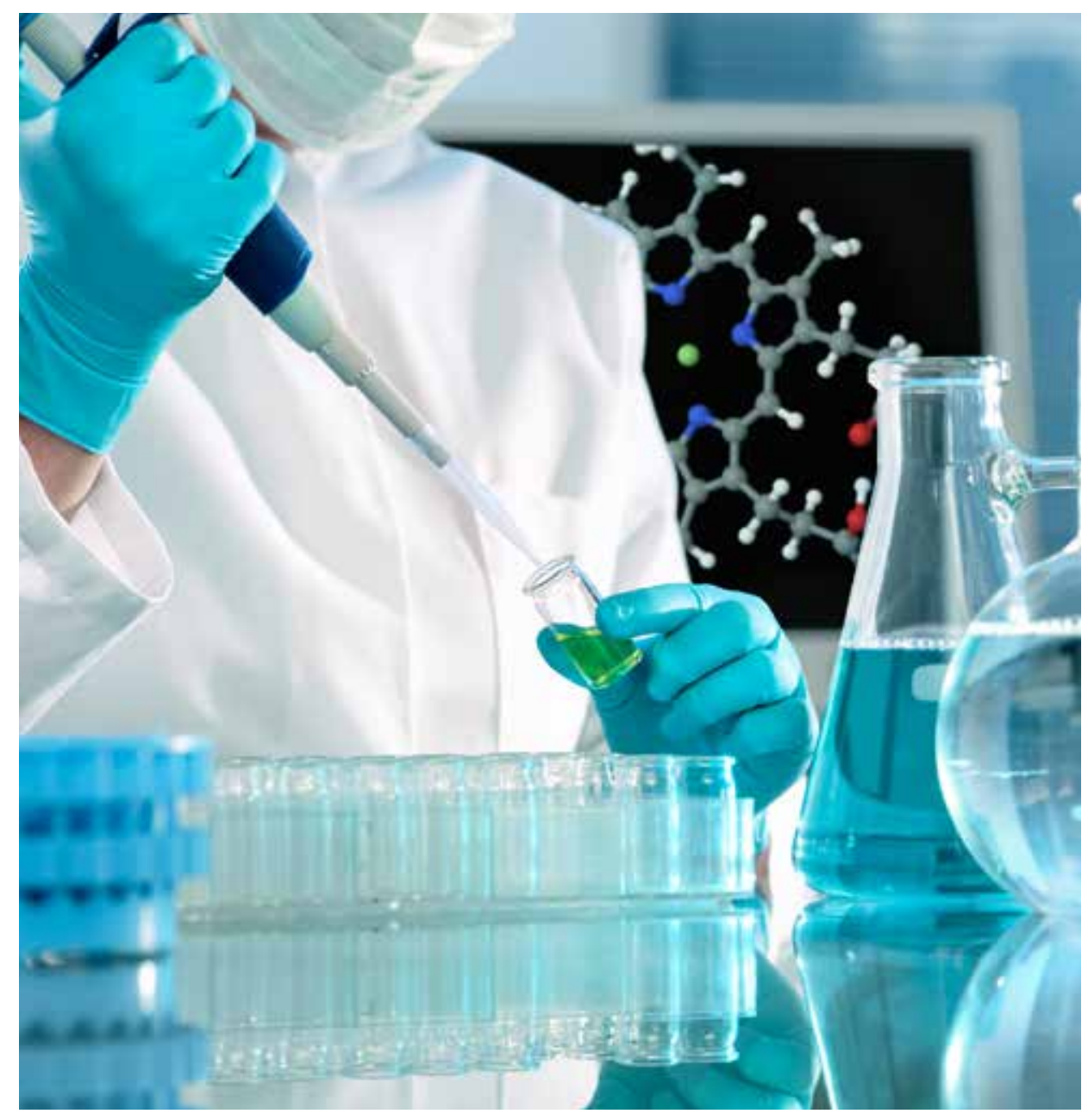




\section{Institutional topics}

Co-operation in the working life area in the Nordic region is characterised by a comprehensive and multifaceted network of relations on many levels. Indeed it is striking in the co-operation between the Nordic countries that this is something that is replicated in all areas, also beyond the co-operation that takes place under the auspices of the Nordic Council of Ministers and the Nordic Council.

On all levels - ministers, the committees of senior officials, the labour market organisations, the relevant administrative branches related to the labour market and university researchers - exchanges of experience and informal and direct forms of co-operation have been emphasised as being amongst the most important and valuable elements. At the same time this emphasis may be interpreted as an expression of the absence of a higher political level of ambition in the co-operation. Before we look into this, it should be noted in all fairness that multifaceted Nordic co-operation as we know it is something that has not been built up in most regions of the world and is something that many envy us for. It is an immense resource to be able to discuss problems and ideas between neighbours who, despite certain differences, can understand each other because they have much in common. This provides the basis for genuine and relevant experiencebuilding and innovation transfer. 


\section{Nordic Council of Ministers for Labour}

A specific objective of this review of working life in the Nordic region is however to make proposals to strengthen Nordic co-operation. Therefore the level of ambition and working method of the Council of Ministers naturally call for closer discussion. It should be emphasised here that the Nordic Council of Ministers for Labour cannot be expected to differ essentially from the other sectoral Councils of Ministers as regards its formal possibilities and limitations in terms of decision-making powers.

It is striking that in the institutional image of the co-operation all sides would like ministerial meetings to be characterised by more substantive political themes, debates and decisions. This desire is not new, but it seems as if everyone is resigned in advance to the view that when it appears unrealistic to expect clear, directly binding decisions from the ministers, not much can be done to improve the political productivity in the system. Comparing the Nordic Council of Ministers for Labour and the Councils of Ministers in most other sectors, however, it must be borne in mind that the reality and political working conditions of a minister for labour are to a large extent defined by the interaction with labour market organisations, whether in formalised tripartite negotiations or in ongoing consultations on e.g. implementation of EU directives or a variety of other issues. Furthermore, this interaction is in practice shaped by the way matters related to working life are dealt with in the country concerned.

Therefore it is somewhat too facile to claim that what is lacking is quite simply political will. There is a common tendency in international organisations (and not only there) to compensate for the absence of interesting genuine political discussion by formalising the agenda to the point where for example adoption of the minutes of the previous meeting resembles a momentous decision. The tendency to fill up the agenda with items that neither stimulate debate nor entail decision can also make the meeting invitation look important, but in reality acts as a time waster, and is anything but motivating for the ministers' personal commitment and investment in active participation in the meetings.

Given the reality of both the formal and political setting of the co-operation in the Nordic Council of Ministers, therefore, it is not appropriate to measure the productivity of a Council of Ministers by the number of decisions it makes that are directly applicable throughout the Nordic region. By contrast, it makes perfect sense to measure the productivity of the co-operation by the quality of the discussions between the minsters directly, by the initiatives they decide to launch together and by the ministers' collective commitment to implement these. At the risk of being misunderstood, it is hard to put it better than that it comes down to making the meetings between the ministers a "good club" rather than an over-formalised meeting machine. The way to increase the political relevance of the Nordic Council of Ministers for Labour is to make participating in this co-operation an attractive, meaningful and necessary part of the ministers' use of their time. In this context it will be necessary in all areas of co-operation to take a pragmatic and unsentimental approach to the language problem.

A prerequisite for this is meaningful and jointly prepared briefings for the ministers and a degree of boldness on their part to raise the ambition level in the co-operation. The decision to carry out the present analysis of working life in the Nordic countries with a view to strengthening Nordic co-operation in this area can be seen as a sign that the ministers have taken the first step in this direction. 
Proposal 9: $\quad$ The agenda for ministerial meetings should be divided into A points, which are not expected to give rise to discussion, and $B$ points, where discussion and possibly decisions are anticipated. This division should be made in the Nordic Committee of Senior Officials for Labour, where ahead of the meetings the senior officials ascertain on behalf of their ministers what points there is agreement on. There should be more scope than hitherto for thematic political debates between the ministers on the basis of presentations produced in broader co-operation.

There are three principal actors in the organisation of meetings between the ministers: the minister for labour in the country holding the Presidency, who will typically have drawn up certain priorities in connection with the country's overall programme for the Presidency. The Nordic Committee of Senior Officials for Labour (EK-A), where officials provide technical/ political speaking points for their respective ministers, which then guide the substance of the discussions. The Secretariat of the Council of Ministers has traditionally had a predominantly logistical and practical support function in the working life area, but the desire for a more robust highlighting of the cross-cutting, joint Nordic perspective suggests that the Secretariat plays a more substantive role in preparing ministerial meetings, in line with the arguments set out in the "New Nordic Region" report. Thus there will be a need for closer co-ordination between these three bodies in conjunction with an upgrading of the Secretariat's role.

The work of the various committees under the Nordic Committee of Senior Officials for Labour should be better integrated into the ministerial meetings. These are: the legal Nordic Industrial Relations Committee, the Labour Market Committee and the Working Environment Committee. The committee on migratory pressures proposed in this report should form part of this process. Above all, the particular legal expertise in the Nordic Industrial Relations Committee should be brought to bear as a fundamental element in the activity described in proposal 12 on the legislative process in the EU.

Proposal 10: The Secretariat of the Nordic Council of Ministers should exercise a more substantive, initiating and co-ordinating role in the preparation of ministerial meetings, both to ensure better coherence and incorporation of the work in the various committees under the Nordic Committee of Senior Officials for Labour and to strengthen the common Nordic dimension in the ministers' discussions.

An unavoidable problem in connection with the whole thinking behind this analysis will naturally be that a higher level of ambition for Nordic co-operation in the working life area, as expressed in this report and in line with the mandate, must necessarily entail increased resources. The ministers for labour cannot be expected to deliver this alone. The governments must address the need to create a balance between the ambition in Nordic co-operation and the resources provided for it.

Proposal 11: The governments must address the need to ensure adequate and stable financing of more ambitious Nordic co-operation in the working life area. 


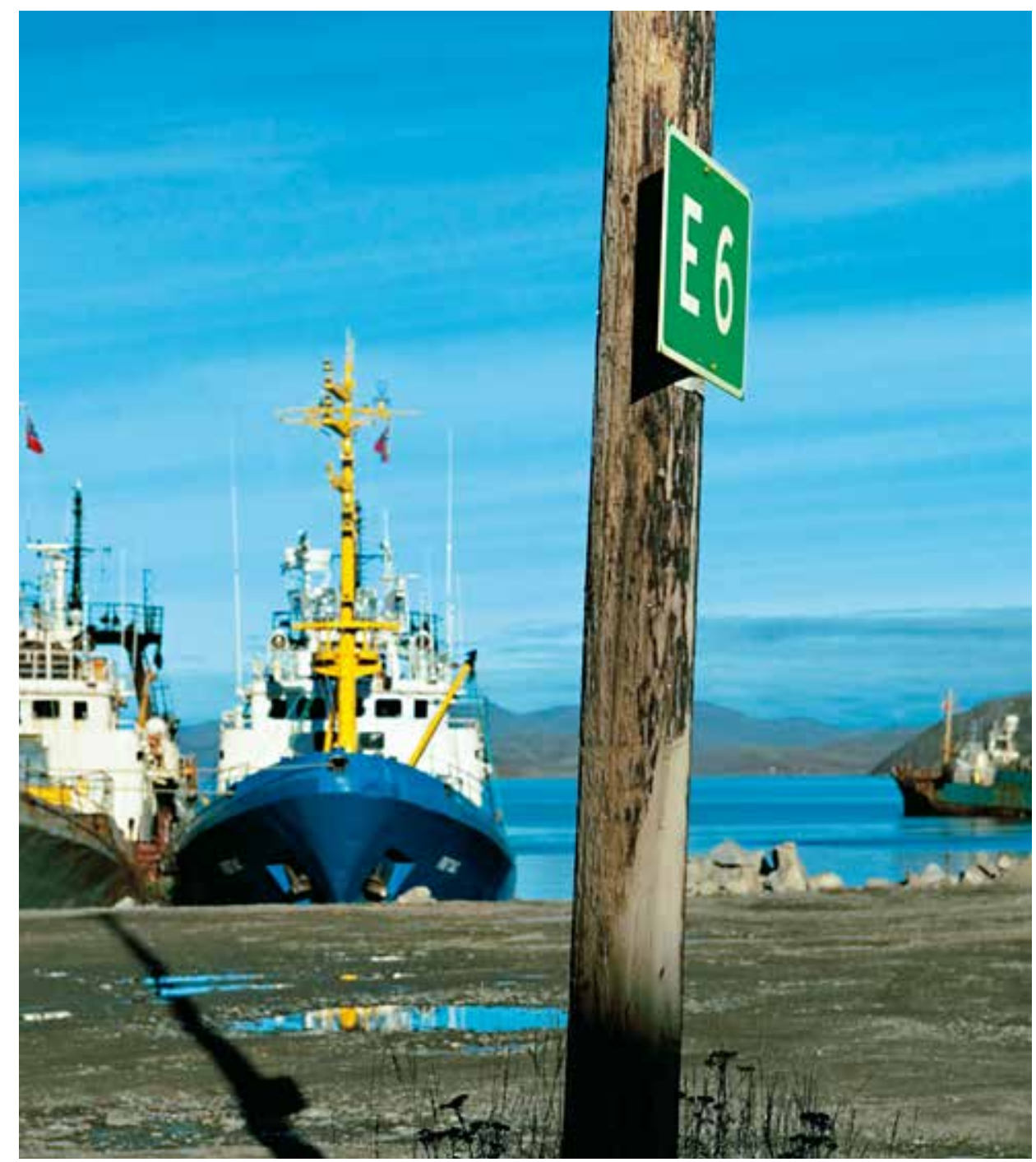




\section{The Nordic region in the EU}

\section{Description}

The endeavour to build up a labour market policy in the EU through a common legislative process is a justified and logical consequence of the consolidation of the single market. Making a reality of freedom of establishment for companies is a clear bonus for Europe's economic development. Safeguarding the rights of migrant workers whilst maintaining respect for collective agreements and rules in general in the Member States' labour markets is an equally essential precondition for attaining a wellfunctioning single market. Striking the right balance between these factors is not merely a technical/legal challenge but also a matter that in many ways is characterised by classic, conflicting interests.

A direct comparison between the prerequisites and conditions for the creation of the common Nordic labour market and the joint European labour market, which following the EU's enlargement in 2004 includes Member States with very different economic and social starting points, illustrates both why it is complicated to create a broadly accepted balance and why in most Member States there is a well-founded interest in building up a Community-based labour market policy.

The Nordic countries differ from most of the rest of the EU's Member States (and for that matter from the rest of the world) in that they have a structure in the labour market with well-defined and representative actors both on the employers' and employees' sides, where the state has a relatively detached role, and where the agreements negotiated by the parties are respected. In contrast, many other countries are characterised by a fragmented and weak organisation structure on both sides of the labour market - or an imbalance in the relationship between them - and a tradition for the legislature to decide many of the conditions that in the Nordic countries are determined through negotiations between the parties.

Therefore the fact that the legislative process in the EU is being used to create a common legal basis for labour market policy is seen as a natural and welcome approach to secure rights and define a certain balance between the various conflicting interests and views. Seen with Nordic eyes, however, this process, regardless of the content of individual directives, is seen as a threat to the core of the model we have built up. There are therefore two layers of questions to address in the relationship between the Nordic model and the legislative process in the EU: the role of the state in relation to freedom of contract between the parties and the specific substantive aspects concerning the content of the directives and their implementation. In both respects there is a need for the Nordic countries to jointly play a more pro-active role to safeguard our viewpoints and interests. 
The question of the relationship between the state as legislator and the parties' freedom of contract goes beyond a matter of principle about institutional power relations. At the workplace, it makes a real difference whether an employee can get support and assistance for mediation from his or her shop steward and trade union, or is forced to seek legal counsel and go to court, with the negative consequences this will inevitably have, both for the continued employment of the person concerned and for the company. The agreement system also has considerable advantages for employers in the form of no-strike (and no lock-out) clauses and stability. Joint ownership of agreements by employees and employers and the existence of a special system of industrial relations based on respect for this creates the basis for trust that is anchored in a different way, and works better in practice, than if the state has dictated the rules.

Labour market policy in the EU requires unanimity in the Council of Ministers. Whilst the Commission has its right of initiative, it does not have the same competence in this area as in e.g. trade policy or other areas. It is therefore necessary to navigate through a more fragmented and situation-specific process using "open co-ordination". It is very difficult to find unanimity for regulations, which are directly applicable in the Member States. Directives, which contain a degree of flexibility in the way individual Member States transpose and implement them in national law, are thus naturally the dominant legal framework for the legislative process in European labour market policy. It is the Commission's job to monitor that the Member States uphold the aims and substance of directives when they implement them. Considering the interests attaching to the entire subject matter, and considering the piecemeal nature of legislation, it is no wonder that cases are continually being brought before the European Court of Justice, whose rulings in reality ultimately determine the content of the EU's policy and legal position in the labour market area.

Therefore the process contributes to a shift in the balance between the parties' freedom of contract and the state as legislator, with the judiciary gaining a central role in defining applicable law. This is not unique to labour market policy in the EU, but is a construction that was created on purpose in order to allow for both mediation and decisive action in the complicated ongoing integration process, and which has generally served European co-operation well. But the contrast, especially in the labour market area, compared with the Nordic model is clear.

The EU Court of Justice bases its rulings on the treaties - including the preamble to the Lisbon Treaty on human rights - and interpretation of legislation in the form of directives and regulations, and it is entirely legitimate for it to emphasise that the rulings are designed to strengthen the fundamental principles for the development of the co-operation in Europe.

The EU Court of Justice, however, is not alone in issuing rulings affecting the labour market in Europe and the Nordic region. Norway and Iceland, like the other EEA countries participating in the EU's single market, are obliged to comply with virtually all the rules adopted in the EU. Compliance with this requirement 
by the EEA countries is monitored by the EFTA Secretariat in a parallel to the Commission's role in the EU. Cases can be brought before the EFTA court, which then also interprets EU legislation and issues final rulings. The third court that issues rulings on labour relations matters is the European Court of Human Rights, the legal basis of which is the European Convention on Human Rights, which deals with matters including the right to organise. Individuals can bring a case before the Court of Human Rights after the national judicial bodies have been exhausted.

All three courts issue final rulings and do so entirely independently of each other. One could object that whilst the rulings might be final, the EU always has the possibility to amend legislation subsequently and thereby have the last word. But in any event such corrective fine-tuning takes quite some time and is no easy matter to complete; all the opposing interests naturally re-emerge. The current process on a revision of the Posting of Workers Directive is a clear illustration of this.
In the light of the piecemeal nature of directives and the very loosely worded principles in the treaties and human rights texts as well as the specific background to the cases that emerge as a consequence of the lack of clarity in Member States' implementation of directives etc., it must be said that the situation does not correspond to what one would expect the judicial authority to look like in a wellorganised democratic political system. But no-one makes an issue of this out of respect for the independence of the courts. Nor does this report contain any proposals for specific initiatives from the Nordic ministers for labour on this point. But it is both legitimate and relevant to lay bare the situation - not least because the Nordic countries, with their somewhat different status as regards the legislative process in the labour market area in Europe, must comply with the rulings of the three courts, and because these rulings directly or indirectly affect the particular balance between the state and the social partners, which is a crucial part of the core of the Nordic model. 


\section{What can the Nordic region do?}

The governments of the Nordic countries and the social partners already invest considerable resources in monitoring and exerting influence on the legislative process in the EU. This work is done in the Industrial Relations Committee (NAU), the ministries in the capitals and the representations in Brussels. However, efforts seem to have centred on each Nordic country highlighting the particular conditions in its labour market policy, and attempting to gain understanding and consideration for these from other countries. What constitutes the legitimacy in this form of optimisation of influence is typically that very specific elements of a proposal can be pointed to that will cause significant practical problems in the country's existing situation, without these elements being central to the aims of the proposal as a whole. This is a form of technical/political consultancy of mutual interest.

Going it alone like this may be justified in the light of nuances in the way the various Nordic countries implement directives, for example, and also it may be easier for the countries to put their views across individually in a more selective and network-based dialogue in the complex decision-making structure in the Commission, Parliament and in negotiations in the Council. The limitation in this method, however, is that it is mostly a reactive and also typically defensive approach, and an approach that does not permit a more general and strategic dialogue on the principles in the legislation. And the main problem for the Nordic countries in the legislative process in the labour market area in Europe is to create better understanding of the fundamental principles, or the core, of the Nordic model, so that we are not faced with greater and greater challenges with one directive after the other.
One of the many persons I spoke to in the work with of the report said of the Nordic region in an international context: "It is difficult to be different". Managing to gain understanding and respect for the core of the Nordic model requires joint efforts of a more general and sustained nature. This applies in relation to the EU and in relation to the world beyond. It is a pedagogical challenge, in which nuances and differences between countries in the labour market area naturally have to be explained, but where the emphasis must be placed on presenting the value of $a$ labour market where there is faith that the parties' agreements will hold, and where in practice their ability to compromise represents a resource for society - both economically and in terms of stability. The Commission's revived Social Dialogue in the EU is an obvious forum where Nordic employers and professional organisations can contribute to understanding and respect for the Nordic model.

As regards the more specific domain of the legislative process in the EU, a more markedly joint Nordic approach would add a substantial and pro-active dimension to the countries' individual efforts. It is not a matter of either-or between an organised joint effort and the countries working individually. But it is necessary for the interests of the Nordic region to be safeguarded more robustly, - not just to avoid rules being adopted that undermine the way the Nordic labour markets function, but also so that the principles, whose value and viability we have demonstrated, are given weight in the future policy formation in the EU.

There is a need therefore both for general visibility - or branding - of the core of the Nordic model and a targeted and more proactive joint defence of Nordic interests, both through the Social Dialogue and in the legislative process in the EU. 
Proposal 12: Following consultations with Nordic employers' and employees' organisations, the ministers for labour should decide in principle to organise stronger joint branding of the core of the Nordic labour market model in an ongoing effort designed to create greater understanding and respect for it both in the revived Social Dialogue in the EU, in the pre-legislative work in the Commission and in more robust pursuance of interests in the negotiating process in Parliament and in Council following submission of a Commission proposal. 


\section{The Nordic region in the world}

\section{International Labour Organisation (ILO)}

The International Labour Organisation will celebrate its centenary in 2019. The ILO has been enormously important globally through its normative work in the conventions, in resolutions of disputes in the expert committee and in project work on capacity building, not least in developing countries. The Nordic countries have played an active role in the ILO over the years, not least because the aims and working methods of the organisation, with direct participation of the employer side and the trade unions, dovetails well with the characteristics of the labour market in the Nordic countries. There is already a well functioning co-operation between the diplomatic representations of the Nordic countries at the ILO in Geneva, which could serve as a starting point for more intensive co-operation between the Nordic countries and the ILO.

The ILO's "Future of Work" centenary initiative contains thorough analysis and comprehensive debates on the world of work. A fundamental part of this project has to do with the representativeness of classic forms of organisation in the labour market in the light of e.g. technological changes, global competition and sectoral shifts in economic life, with a rapid increase in "self-employment" or informal single-proprietor arrangements without the security and clarity for the individual that are part of the traditional employment relationship. Not least in developing countries - but to a large extent also in developed countries - this involves a blurring of the border between the informal and the formal economy and represents an impediment to the construction of a regular contractual labour market, where the obligations and rights of both employers and employees are set out clearly. In 2017 the ILO will organise a panel on the representativeness of the social partners, which is an illustration of the fundamental importance accorded to the creation and maintenance of well-organised labour markets.

The ILO welcomes the active commitment of the Nordic countries in a dialogue on this challenge. Since the labour market model in the Nordic region functions well by international comparison, there is an expectation that we in particular will have an input of ideas into the "Future of Work"process.

The same applies in the area of statistics, where closer co-operation with the Nordic group is welcomed.

When discussing the attractiveness of the Nordic model and its possible application round the world, the ILO is a natural platform for showcasing both freedom of contract as the core of the model and the variations that exist from country to country in the Nordic region, and the broader social policy preconditions, both historical and cultural, that are related preconditions for the existence and functioning of the model. What is interesting in a joint Nordic commitment to this discussion is the extent to which Nordic experiences can be selectively transferred and adapted to other countries that see the Nordic model as an inspiration. However difficult this discussion is, it will be meaningful for our own self-image and for the sustainability of the model in a globalised world, where it is difficult to be different. 


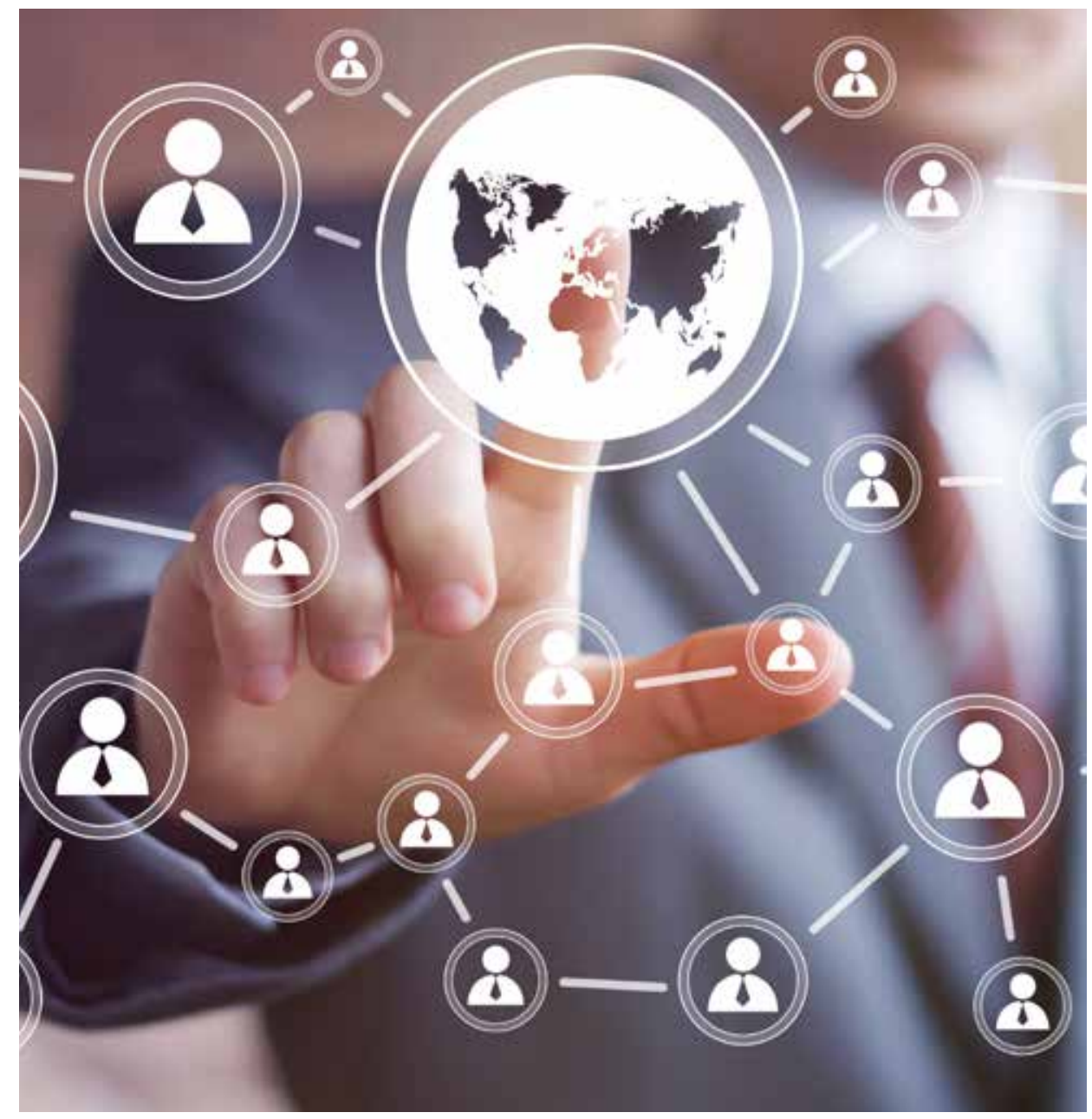

Proposal 13: The Nordic Council of Ministers for Labour should intensify cooperation with the ILO as part of the "Future of Work" project, work to improve labour market statistics internationally and the general dialogue on dissemination and understanding of the fundamental principles in the Nordic model. This work should be conducted in the broadest possible context in close co-operation with Nordic employers' and employees' organisations. 


\section{OECD}

The OECD has a fundamental role in the ongoing international debate on the principles and nature of economic policy in developed countries. The organisation is both a highly qualified institutionalised think-tank and an actor which in its country examinations voices criticism and recommendations on member countries' economic policy generally. There is a clear acknowledgement in this work of the difference that exists between the American/Anglo-Saxon economic model of society and the Nordic welfare societies with their negotiating model in the labour market, which thus represents an alternative in the international debate on economic principles. It is also acknowledged that the economic achievements of the Nordic countries contribute to stimulating interest in the Nordic model.

This of course makes the OECD an important partner of the Nordic countries in general in the endeavour to create international understanding for the way in which our societies - and not least the labour market - operate. But, in addition to that, the OECD's analytical and inspirational work in a number of areas is of direct interest for the challenges we face in the Nordic labour markets: the connection between labour market trends and the demographic trend towards an older population make-up; the growth in mental problems in working life; the fragmentation of working life (the selfemployment challenge), where the OECD has launched a systematic analysis; improved statistics, where the OECD welcomes closer co-operation with the Nordic region; the education and training area, where a high priority is given to reforms of adult education; and an initiative to extend national GDP models ("Better Life Initiative") to include factors such as human well-being, social security etc. in a more qualitative calculation than the traditional GDP measure.

All this speaks in favour of resources being put into a direct and active involvement in these areas in Nordic co-operation in the OECD - both to facilitate a qualitatively direct input into joint policy development in the Nordic region, and so that the ideas and views that have their roots in the Nordic model are fed into globally oriented policy development in the OECD. Cooperation between the Nordic region and the OECD both generally and in these areas should be followed up by substantive thematic discussions at the meetings of the Nordic Council of Ministers for Labour on the basis of co-operation between the Nordic countries' representations at the OECD Secretariat and the departments at home and prepared and co-ordinated by the Secretariat.

Proposal 14: The Nordic Council of Ministers for Labour should decide to upgrade Nordic co-operation in the OECD, both in the dialogue on fundamental principles in economic policy and the many fundamental areas relevant to labour market policy indicated here. In view of the horizontal aspects of these problem areas, preparation of the subsequent thematic discussions in the Nordic Council of Ministers for Labour should be co-ordinated by the Secretariat. 



\section{norden}

\section{Nordic Council of Ministers}

Ved Stranden 18

DK-1061 Copenhagen

www.norden.org

\section{Working life in the Nordic region - Challenges and proposals}

Apart from a number of differences between the countries in the Nordic region as regards the structure and policies of their labour markets generally, there is a core of common types of employment, standards and values which together define the nature of working life and labour market policy in the Nordic countries so that one can speak of a "Nordic model", which in fundamental areas is distinct from conditions in the labour market in most other countries - both in Europe and the rest of the world.

The challenges and the opportunities for identifying new ideas that could strengthen co-operation in the Nordic region in the field of working life can be divided into four categories:

- Substantive, common Nordic topics

- Institutional topics in Nordic co-operation

- The Nordic labour market and the EU

- The Nordic region in the world. 